\title{
HUBUNGAN JENIS SUMBER AIR DAN PERSONAL HYGIENE DENGAN KEJADIAN PENYAKIT DERMATITIS DI DESA KEDUNGRANDU KECAMATAN PATIKRAJA KABUPATEN BANYUMAS TAHUN 2016
}

\author{
Presilia Jesika $^{1)}$, Nur Hilal ${ }^{2)}$, Khomsatun ${ }^{3)}$ \\ Jurusan Kesehatan Lingkungan, Politeknik Kesehatan Kemenkes Semarang, \\ Jl.Raya Baturaden KM 12 Purwokerto, Indonesia
}

\begin{abstract}
Abstrak
Dermatitis merupakan peradangan kulit sebagai respon terhadap pengaruh faktor-faktor lingkungan seperti polutan dan alergen-alergen. Data Dinas Kesehatan Banyumas Tahun 2015 kasus Dermatitis tertinggi Kecamatan Patikraja 1.358 pasien. Bulan Nopember tahun 2015, pasien Dermatitis tertinggi 138 orang di Desa Kedungrandu. Wilayah Desa Kedungrandu merupakan lokasi Tempat Pembuangan Akhir Gunung Tugel dimana tempat pembuangan akhir gunung tugel merupakan yang terbesar di Banyumas. Tujuan penelitian ini untuk menganalisis hubungan jenis sumber air dan personal hygiene dengan kejadian Dermatitis Metode penelitian yang digunakan adalah observasi dan case control dengan 27 responden kasus dan 27 responden kontrol. Variabel penelitian ini sarana sumber air dan personal hygiene yang terdiri dari perilaku mandi, perilaku berpakaian dan perilaku tidur. Analisis menggunakan analisis SPSS versi 1.7 dengan uji chi-square dengan $\alpha 0,05$. Hasil penelitian menunjukkan variabel yang memiliki hubungan dengan kejadian penyakit Dermatitis adalah jenis sumber air dengan nilai p value=0,001, personal hygiene merupakan variabel yang tidak mimiliki hubungan dengan kejadian penyakit Dermatitis di Desa Kedungrandu dengan hasil nilai p value = 1,000. Kesimpulan penelitian yaitu jenis sumber air dapat menjadi salah satu faktor penyebab Dermatitis di Desa Kedungarandu. Peneliti menyarankan dari pihak puskesmas meningkatkan kerja sama dengan pemerintah desa untuk melakukan penyuluhan dan meningkatkan program kesehatan lingkungan.
\end{abstract}

Kata kunci : Dermatitis, casecontrol, kedungrandu, kesehatan lingkungan

\begin{abstract}
Dermatitis is an inflammation of the skin (epidermis and dermis) as a response to the influence of environmental factors such as pollutants and allergens. In the Kedungrandu area Patiktaja District Banyumas Regency data obtained from Banyumas Health Department In 2015 the highest number Dermatitis cases in Patikraja District was 1,358 patients. In November 2015 Dermatitis patients was 138 people, highest in Kedungrandu Sub-district. The Research objective was analyze the correlation between personal hygiene and clean water source with Dermatitis incidence. The research method used was observation and case control which was 27 respondents as cases and 27 respondents as control. The variables in this study was water sources and personal hygiene consisting of behavioral bathing, dressing behavior and sleep behavior. The data Analysis conducted using SPSS version 1.7 through chi-square test with $0.05 \alpha$. The analysis results showed that variables that have significant correlation with Dermatitis incidence was water source with $\mathrm{p}$ value $=0,001$, personal hygiene had no significant correlation with Dermatitis incidence $\mathrm{p}$ value $=1.000$. The conclusion drawn was water sources could be one factor that causes Dermatitis in Kedungarandu Sub-district. Researchers suggest the Public Health Center to improve cooperation with village officials to conduct counselling and improve the environmental health program.
\end{abstract}

\section{Kata kunci $\quad$ :Dermatitis, case control, kedungrandu, Environmental Health}

\footnotetext{
1) E-mail: presiliajeje16@gmail.com

2) E-mail: inung.nh@gmail.com

3) E-mail: khomsatun@yahoo.co.id
} 


\section{PENDAHULUAN}

Menurut H. L. Blum ada 4 faktor yang mempengaruhi status derajat kesehatan masyarakat atau perorangan. Faktor-faktor tersebut faktor perilaku yang lebih dominan dibandingkan dengan faktor lingkungan Hal ini disebabkan oleh lingkungan hidup manusia juga sangat dipengaruhi oleh perilaku manusianya. (Irma Marisa,2015).

Program PHBS yang telah dicanangkan pemerintah merupakan program prioritas pemerintah karena buruknya kondisi lingkungan yang belum baik dan perilaku hidup bersih dan sehat di masyarakat, diduga menjadi penyebab permasalahan kesehatan dengan masih tingginya angka penyakit infeksi dan peningkatan penyakit degeneratif (Departemen Kesehatan Republik Indonesia, 2006), salah satunya penyakit kulit Dermatitis.

Dermatitis adalah peradangan kulit (epidermis dan dermis) sebagai respon terhadap pengaruh faktor eksogen dan atau faktor endogen, menimbulkan kelainan klinis berupa eflorensasi polimorfik (eritama, edema, papul, vesikel, skuama, likenifikasi) dan keluhan gatal. Tanda polimorfik tidak timbul bersamaan, bahakan mungkin hanya beberapa (oligomorfik). Dermatitis cenderung residif dan menjadi kronis. (Sri Adi Sularsito dan Suri Djuanda, 2010)

Menurut Danisa Diandra Safarina (2014) Faktor-faktor lingkungan seperti polutan dan alergen-alergen mungkin memicu terjadinya Dermatitis pada individu yang rentan, seperti:

a. Polutan: asap rokok, peningkatan polusi udara, pemakaian pemanas ruangan sehingga terjadi peningkatan suhu dan penurunan kelembaban udara, penggunaan pendingin ruangan.

b. Alergen: tungau debu rumah, serbuk sari buah, bulu binatang, jamur, kecoa

c. Makanan: susu, telur, kacang, ikan laut, kerang laut dan gandum

d. Mikroorganisme: Staphylococcus aureus, Streptococcus sp, P.ovale, Candida albicans, Trycophyton sp.

Pemukiman sehat merupakan salah satu program kesehatan lingkungan, suatu pemukiman yang sehat sangat berhubungan dengan ekonomi, sosial, pendidikan, tradisi/ kebiasaan, suku, geografis, dan kondisi lokal. (H. J. Mukono, 2006). Pemukiman di Patikraja yang berpotensi mengalami masalah personal hygiene dan jenis sumber air yang mengakibatkan terjadinya penyakit Dermatitis yaitu di Desa Kedungrandu. Desa tersebut merupakan lokasi Tempat Pembuangan Akhir Gunung Tugel dimana tempat pembuangan akhir gunung tugel merupakan yang terbesar di Banyumas

Tujuan dari penelitian ini adalah untuk menganalisis hubungan jenis sumber air dan personal hygiene dengan kejadian Dermatitis.

\section{BAHAN DAN METODE}

Jenis penelitian ini adalah observasional dan case control yaitu dengan 27 responden kasus dan 27 responden kontrol. Variabel penelitian ini sarana sumber air dan personal hygiene yang terdiri dari perilaku mandi, perilaku berpakaian dan perilaku tidur. Penelitian ini menggunkan kuesioner dan cek list untuk mendapatkan informasi yang diperlukan. Hasil observasi dan wawancara dianalisis menggunakan soft ware analisis data yang terdiri dari analisis univariate untuk menggambarkan tiap variabel, analisis bivariate menggunakan uji regresi sederhana.

\section{HASIL DAN PEMBAHASAN Univariat}

Jenis kelamin responden data kasus Dermatitis bulan Desember tahun 2015 yang diperoleh dari Puskesmas Patikraja sebagian besar yaitu perempuan dengan jumlah 16 orang $(59,3 \%)$ kasus dan 11 orang $(40,7 \%)$ laki-laki kasus. Jumlah kelompok sebagai kontrol disesuaikan dengan jumlah data kasus yaitu perempuan 16 orang (59\%) dan 11 orang $(41 \%)$ laki-laki, dengan total jumlah responden laki-laki kelompok kasus maupun kontrol sejumlah 22 orang $(40,7 \%)$ dan jumlah keseluruhan perempuan 32 orang $(59,3 \%)$.

Usia responden kelompok kasus pada usia $<21$ tahun sejumlah 15 orang $(55,6 \%)$ kontrol sejumlah 15 orang $(55,6 \%)$, jumlah kelompok kasus usia 21-51 tahun sejumlah 5 orang $(18,5 \%)$ kelompok kontrol sejumlah 7 orang $(22,2 \%)$, dan jumlah kelompok pada usia $>51$ tahun kelompok kasus 7 orang $(25,9 \%)$ dan kelompok kontrol 5 (55,6\%), jumlah keseluruhan 
kelompok kasus maupun kelompok kontrol dengan usia $<21$ tahun sejumlah 30 orang (55,6\%), jumlah usia antara 21-51 tahun yaitu sejumlah 12 orang $(22,2 \%)$, dan usia $>51$ tahun sejumlah 12 orang $(22,2 \%)$.

Jenis Sumber Air yang digunakan oleh responden yaitu ada 3 terdiri dari sumur gali, PDAM, mata air. Pada kelompok kasus yang menggunakan sumur gali sejumlah 26 (96,3\%), menggunakan PDAM $0(0 \%)$ atau tidak ada yang menggunakan jenis air bersih PDAM, dan yang menggunakan jenis mata air 1 (3,7), sedangkan pada kelompok kontrol yang menggunakanjenis sumur gali sejumlah 16 (59,3\%), yang menggunakan jenis PDAM $11(40,7 \%)$, dan pada kelompok kontrol tidak ada yang menggunakan jenis mata air $0(0 \%)$. Jumlah keseluruhan responden yang menggunakan sumur gali dari kelompok kasus maupun kelompok kontrol sejumlah 42 (77,8\%), PDAM sejumlah $11(20,4 \%)$, dan jumlah penggunaan mata air 1 (1,9\%). Reponden yang menggunakan sumur gali dan mata air berisiko lebih besar terkena penyakit kulit salah satunya Dermatitis, karena berdasarkan observasi sumur gali yang tidak ditutup dapat tercemar secara fisik yaitu tercemar oleh daun, ranting dan kotoran lain. Sedangkan dinding sumur yang retak dapat menyebabkan pencemaran mikrobiologi dan kimia yang dikarena oleh letak sumur dekat dengan sumber pencemar biologi seperti kandang dan jamban dan sumber pencemar kimia seperti limbah hasil mencucian baju dan piring.

Menurut Santoso (2010) air yang berkualitas harus memenuhi persyaratan fisik yaitu tidak berwarna, tidak berasa dan tidak berbau.Air merupakan hal yang esensial bagi kesehatan, tidak hanya dalam upaya produksi tetapi juga untuk konsumsi domestik dan pemanfaatanya (minum, memasak, mandi, dll). Promosi yang meningkat dari penyakit infeksi yang mematikan maupun merugikan kesehatan ditularkan melalui air yang sudah tercemar, sebagian penyakit yang berkaiatan dengan air bersifat menular. Kurangnya air bersih khususnya untuk menjaga kebersihan diri dapat menimbulkan berbagai penyakit kulit. (Notobroto, 2005)

Kuantitas Air kelompok kasus yang jenis sumber airnya mencukupi sejumlah 23 orang $(85,2 \%)$, kelompok kasus yang airnya tidak mencukupi sejumlah 4 orang $(14,8 \%)$, sedangkan pada kelompok kontrol jenis sumber airnya mencukupi sejumlah 27 (100\%) yang artinya tidak ada kelompok kontrol yang airnya tidak mencukupi $0(0 \%)$. Jumlah keseluruhan yang sumber airnya mencukupi dari kelompok kasus maupun kelompok kontrol sejumlah $50(92,6 \%)$ dan sumber airnya yang tidak mencukupi sejumlah $4(7,4 \%)$.

Personal Hygiene Diketahui kelompok kasus dengan personal hygiene cukup baik yaitu 12 orang $(44,4 \%)$, personal hygiene baik 15 (27\%), sedangkan pada kelompok kontrol perilaku personal hygiene cukup baik 11 orang $(40,7 \%)$ dan responden kontrol dengan personal hygiene baik sejumlah 16 (59,3\%). Jumlah keseluruhan personal hygiene cukup baik dari kelompok kasus maupun keleompok kontrol sejumlah $23(42,6 \%)$ dan perilaku personal hygiene baik sejumlah $31(57,4 \%)$. Hasil tersebut dapat dilihat bahwa personal hygiene kelompok kasus dapat berisiko terkena penyalit kulit Dermatitis seperti menurut Price\& Wilson, (2005) yaitu penyakit kulit mudah menginfeksi bila kebiasaan tidak menjaga kebersihan, terutama kebersihan pribadi. Penerapan kebersihan pribadi maka dapat menghindari penyebab terjadinya penyakit kulit salah satunya Dermatitis.

\section{Bivariat}

Jenis Sumber Air Kelompok kasus yang menggunakan sumur gali sejumlah 26 $(96,3 \%)$, menggunakan PDAM $0(0 \%)$ atau tidak ada yang menggunakan jenis air bersih PDAM, dan yang menggunakan jenis mata air 1 (3,7), sedangkan pada kelompok kontrol yang menggunakana jenis sumur gali sejumlah $16(59,3 \%)$, yang menggunakan jenis PDAM $11(40,7 \%)$, dan pada kelompok kontrol tidak ada yang menggunakan jenis mata air $0(0 \%)$. Hasil uji statistik chi square menunjukkan dengan nilai $\mathrm{p}$ value 0,001 dengan demikian nilai $\mathrm{p}$ value lebih kecil dari $\alpha=0,05$ maka Ho ditolak, artinya ada hubungan jenis sumber air dengan kejadian penyakit Dermatitis. Desa Kedungrandu merupakan wilayah Tempat Pembuangan Akhir Gunung Tugel terbesar di Bayumas. Jenis sumur gali yang tidak memenuhi syarat dapat berisiko terkontaminasi pencemaran akibat rembesan dari aktivitas tempat pembungan akhir gunung tugel. Menurut DIT.JEN PPM \& 
PLP (1991) sumur gali dapat dimanfaatkan sebagai sumber air bersih, agar sumur gali tidak tercemar oleh bakteri atau virus ada persyaratan sumur gali diantaranya pada lokasi sumur gali tidak dekat dengan sumber pencemar (kandang ternak, TPS, dll) pada konstruksi sumur gali tertutup pada kedalaman sumur gali diplester 3 meter dan pada kedalaman selanjutnya 1,5 meter dipasang batu bata sehingga tidak menjadi perembesnya air ke sumur gali tidak, pada bibir sumur tidak di tembok kedap air setinggi $70 \mathrm{~cm}$ dinding dengan mulut sumur gali tinggi dari permukaan tanah $70-75 \mathrm{~cm}$, pada lantai sumur gali dibuat tembok (kedap air) $\pm 1,5 \mathrm{~m}$ lebarnya dari dinding sumur agar air permukaan tidak masuk dan untuk saluran limbah dibuat dari tembok (kedap air) jaraknya sekurang-kuranya $10 \mathrm{~m}$.

Sumur gali pada masyarakat yang tidakmemenuhi persyaratan sebaiknya segera diperbaiki konstruksinya, seperti : jarak sumur dengan sember pencemar (kandang ternak, TPS dll), didnding sumur, bibir sumur, dan lantai sumurnya agar sumber air tidak tercemar dan air tidak mengandung bakteri dan virus, salah satu cara untuk menjaga sumur gali dengan menggunakan cara desinfeksi. Metode chlorine diffuser digunakan untuk mencegah ataupun menanggulangi pencemaran bakteri pada sumber air.

Penggunaan jenis sumber air sistem perpipaan dikelola oleh Perusahaan Daerah Air Minum (PDAM) sebagai perlindungan kualiatas air dengan pengelolaan bahan air yang ada dalam parameter kualitas air. Sumber air bakudiperoleh dari air permukaan dan air tanah, sebelum dialirkan ke pelanggan dibubuhi kaporit sebagai desinfektan, sedangkan air baku dari air kali sebelum kepelanggan dilakukan penjernihan melalui saringan pasir, bak sedimentasi, saringan pasir cepat dan desinfeksi. Pengelolaan air bawah tanah dari sumur dalam dilakukan dengan aerasi, kougulasi, flokulasi, filtrasi dan pembubuhan kaporit sebagai disenfektan. Untuk air baku dari sumur dangkal menggunakan penjernihan dengan saringan pasir cepat dan pemberian desinfektan berupa kaporit. (Ridho Adiputra Tabunan, 2014)

Sumber air bersih yang memenuhi syarat adalah paling sedikit jaraknya 10 meter dari sumber pencemar seperti penampungan air kotor, tempat pembuangan sampah, jamban/ kakus. Menurut Depkes RI (2007), kegiatan yang dapat dilakukan keluarga adalah:

a. Ambil air dari sumber air yang bersih

b. Tempat penampungan air harus selalu bersih

c. Wadah penyimpanan air harus tertutup dan sering dibersihkan

d. Gayung pengambil air juga harus bersih Sebaiknya masyarakat menutup sumur gali saat tidak digunakan, menutup sumur gali dapat dilakukan dengan seng, kayu dan lain-lain. Diharapkan untuk pihak puskesmas memberikan penyuluhan dan pelatihan tentang sanitasi lingkungan salah satunya air bersih dan jenis sumber air yang terlindungi.

Personal hygiene kelompok kasus dengan cukup baik sejumlah 12 orang $(44,4 \%)$, personal hygiene baik sejumlah 15 (27\%), sedangkan pada kelompok kontrol perilaku personal hygiene cukup baik sejumlah 11 orang $(40,7 \%)$ dan responden kontrol dengan personal hygiene baik sejumlah 16 (59,3\%). Hasil uji statistik chi square menunjukkan dengan nilai $\mathrm{p}$ value 1,000 dengan demikian nilai $\mathrm{p}$ value lebih kecil dari $\alpha=0,05$ maka Ho diterima, artinya tidak ada hubungan jenis sumber air dengan kejadian penyakit Dermatitis. Hasil analisis data personal hygiene yang terdiri dari perilaku mandi, perilaku berpakaian dan perilaku tidur menunjukkan tidak ada hubungan personal hygiene dengan kejadian penyakit Dermatitis di Desa Kedungrandu. Berdasarkan hasil observasi personal hygiene masyarakat Desa Kedungrandu sudah menunjukkan hasil baik, dilihat dari perilaku mandi masyarakat yang mandi yang diantaranya minimal 2 kali sehari, mandi menggunakan sabun mandi, membersihkan rambut minimal 2 hari sekali dan menggunakan handuk milik pribadi yang dicuci minimal 1 minggu sekali. Hal ini seperti menurut (Intan Silviana Mustikawati, 2013) mandi adalah bagian perawatan hygiene total.Mandi dapat dikategorikan sebagai pembersihan. Hal-hal yang perlu diperhatikan dalam memelihara kebersihan kulit yaitu :

a. Menggunakan barang-barang keperluan sehari-hari milik sendiri

b. Mandi minimal 2 kali sehari 
c. Mandi memakai sabun menjaga kebersihan pakaian

d. Menjaga kebersihan lingkungan

Perilaku berpakaian masyarakat

Desa Kedungrandu dari hasil observasi juga sudah baik diantaranya seperti menggunakan pakaian yang sudah dicuci menggunakan sabun dan disetrika, serta mengganti pakaian minimal sehari sekali dan menggunakan pakaian milik pribadi, serta perilaku tidur masyarakat Desa Kedungrandu juga sudah baik seperti diantaranya menganti speri dan sarung bantal minimal 1 minggu sekali, tidak menggunakan 1 selimut dengan orang lain dan sebelum tidur membersihkan tempat tidur terlebih dahulu. Hasil tersebut sesuai dengan pendapat Hidayat. A (2010) yang menyatakan bahwa banyak gangguan kesehatan yang diderita seseorang apabila tidak terpeliharanya personal hygiene dengan baik.

Kejadian penyakit Dermatitisdi Desa Kedungrandu dimungkinkan karena faktor lain seperti dari jenis sumber air, alergi dan lain-lain. Hasil tersebut dilihat dari hasil observasi yang telah dilakukan yang mana menunjukkan ada hubungan antara jenis sumber air bersih dengan kejadian penyakit Dermatitis di Desa Kedungrandu.Jenis sumber air bersih yang digunakan penduduk Desa Kedungrandu sebagian besar adalah sumur gali. Penggunaan jenis sumber air dengan sumur gali yang tidak memenuhi persyaratan dapat berisiko mengkontaminasi air yang terdapat pada sumur gali tersebut, sedangkan air adalah salah satu prioritas utama yang digunakan dalam kehidupan sehari-hari seperti mandi, mencuci, memasak, dan kebutuhan lainnya. Apabila air tercemar, maka akan mengakibatkan gangguan kesehatan terhadap penggunanya, dan salah satu gangguan kesehatan yang ditimbulkan, yaitu Dermatitis.

Hasil observasi juga menunjukkan bahwa kemungkinan Dermatitis beberapa responden kasus terkena alergi terhadap beberapa jenis makanan hal ini seperti menurut Sri Adi Sularsito dan Suri Djuanda, (2010), ada beberapa jenis Dermatitis yaitu salah satunya Dermatitis kontak (Dermatitis kontak iritan dan Dermatitis kontak alergik). Beberapa orang memiliki kulit yang sensitiv karena alergi makanan, faktor genetik, stres fisik dan mental, serta iritasi. Dermatitis dapat menyerang siapa saja pada usia berapapun dan mempengaruhi setiap bagian dari tubuh. Penderita Dermatitis dapat menderita leih dari satu jenis Dermatitis pada satu waktu yang bersamaan atau bergantian.

Kulit sebagai penghalang, pelindung segala sesuatu yang ada di dalam tubuh dan menjaga supaya tidak ada benda asing dari luar yang masuk ke dalam tubuh. Tapi kulit kita juga memiliki sel-sel khusus dari sistem kekebalan tubuh. Sel-sel ini melindungi kulit dan tubuh terhadap virus, bakteri, dan ancaman lainnya. Setiap kali sel-sel ini mendeteksi zat yang mencurigakan, mereka memulai reaksi berantai pada kulit yang menyebabkan peradangan apabila kontak, karena personal hygiene masyarakat Desa Kedungrandu sudah baik, maka kemungkinan kejadian Dermatitis yang diderita masayarakat Desa Kedungrandu bukan, karena personal hygiene, tetapi karena jenis sumber air dan faktor resiko lainnya.

Meskipun tidak ada hubungan antara personal hygiene dengan kejadian penyakit Dermatitis masyarakat memilki personal hygiene tidak baik harus meningkatkan personal hygiene karena dapat berisiko terkena penyakit kulit.

Keterbatasan peneliti dalam penelitian ini yaitu peneliti tidak memeriksa kualitas air pada setiap sampel jenis sumber air, sehingga jenis sumber air tidak dapat dilihat dari kulitas airnya.

\section{SIMPULAN DAN SARAN Simpulan}

Jenis sumber air yang digunakan masyarakat di Desa Kedungrandu meliputi sumur gali, mata air, tangki air bersih dan PDAM sebagian besar penduduk menggunakan jenis sumber air bersih sumur gali jumlah yaitu sumur gali $90 \%$, mata air $1 \%$, tangki air bersih $0 \%$, dan PDAM 9\%. Keseluruhan responden paling banyak menggunakan sumur gali yaitu 78\%, PDAM $20 \%$ dan Mata air 2\%.

Personal hygiene masyarakat di Desa Kedungrandu, Kecamatan Patikraja, Kabupaten Banyumas dalam hal berperilaku mandi, berperilaku berpakaian, dan perilaku tidur sudah baik. Tidak ada hubungan antara personal hygiene, yang dengan kejadian 
penyakit Dermatitis. Ada hubungan antara jenis sumber air yang digunakan oleh masyarakat sehari-hari dengan kejadian penyakit Dermatitis di Desa Kedungrandu, Kecamatan Patikraja, Kabupaten Banyumas.

\section{Saran}

Meningkatkan penyulahan kesehatan dan Meningkatkan kerja sama dengan pemerintah Desa Kedungrandu terutama dalam hal kesehatan, yang dibantu oleh kader desa atau desa wisma salah satunya kesehatan sanitasi lingkungan untuk mengatasi dan mencegah penyakit berbasis lingkungan.

\section{DAFTAR PUSTAKA}

Achmadi, U.F., 2008. Manajemen Penyakit Berbasis Wilayah. Jakarta: UI Press.

Btari Sekar Saraswati Ardana Putri, 2011, Hubungan Higiene Perseorangan, Sanitasi Lingkungan dan Status Gizi Terhadap Kejadian Skabies pada Anak, Semarang : Univesitas Diponegoro Semarang

Danisa Diandra Safarina, 2014, Karakteristik Penderita Dermatitis Atopik di Poliklinik RSUP Dr. karyadi Semarang, Semarang : Univesitas Diponegoro Semarang

Departemen Kesehatan RI, "Pedoman Pelaksanaan Kesehatan Gigi dan Mulut, Indonesia Sehat 2010". Jakarta 2000

Departenmen Kesehatan RI, 2006, tentang Program Promosi Kesehatan Prilaku Hidup Bersih dan Sehat, Jakarta : Departemen Kesehatan RI

Ditjen PPM dan PLP Depkes (1991). Manual Teknis Upaya Penyehatan Air. Direktorat Jenderal Pemberantasan Penyakit Menular dan Penyehatan Lingkungan Permukiman. Jakarta.

Djamaludin Ramlan, Maisye Marlyn Kuhu, 2013. Petunjuk Praktis Penulisan Penelitian Eksplanatif, Purwokerto : UPT Percetakan dan Penerbitan Universitas Jedral Soedirman

Djasio Sanropie,1984. Penyehatan Air Bersih, Jakarta : Pusat Pendidikan dan Latihan Pegawai

Faizal Ayun Saefurahma, 2015, Hubungan Sanitasi Lingkungan dan PHBS dengan Kejadian Diare pada Balita di Desa Kebumen Wilayah Kerja
Puskesmas I Baturraden, Purwokerto : Poloiteknik Kementrian Kesehatan Semarang

Hidayat, A. 2010. Konsep Personal Hygiene. Yogyakarta: Graha Ilmu

H.J. Mukono, 2006, Prinsip Dasar Kesehatan Lingkungan, Surabaya : Airlangga University Press Surabaya

Intan Silviana Mustikawati, 2013, Perilaku Personal Hygiene pada Pemulung di TPA Kedaung Wetan Tangerang, Jakarta : Universitas Esa Unggul, Jakarta

Irma Marisa, 2015, Teori Hendrik L Blum, On line. Tersedia : http://infokesehatan-bidan-irmamarisa.blogspot.co.id/2015/06/teori -hendrik-l-blum.html, diakses 02 Febuari 2016

Juli Soemirat Slamet, 2004. Kesehatan Lingkungan, Yogyakarta : Gadjah Mada University Press.

Kusnoputranto, H., Suana, D. 2000. Kesehatan Lingkungan, Depok : Fakultas Kesehatan Masyarakat Universitas Indonesia

Mithia Rahimah, Kartini, Muzakkir, 2014 Faktor-faktor yang Berhubungan dengan Kejadian Penyakit Dermatitis pada Narapidana di Rutan Kelas I Makassar Stikes Nani Hasanuddin Makasar

Mulia, Ricky, M, 2005. Kesehatan Lingkungan. Yogyakarta : Graha Ilmu

Notoatmodjo, S, (2003). Pendidikan dan Prilaku Kesehatan, Jakarta : Rineka Cipta.

N. A. Dwi Putri, 2011, Studi pada Daerah Aliran Sungai Siak Bagian Hilir, Tanjungpinang : Universitas Maritim Raja Ali Haji

Peraturan Menteri Kesehatan RI No. 416/ MENKES/IX/1990 tentang Air Bersih.

Potter \& Perry, (2005). Buku Ajar Fundamental Keperawatan, Konsep, Proses dan Praktik, Edisi Keempat, Volume Kedua, Jakarta : EGC.

Putri Sortaria Permata Tarigan, 2008, Hubungan Kerentanan Kondisi Fisik, Sanitasi Dasar Rumah dan Tingkat Risiko Lokasi Permukiman Penduduk dengan Riwayat 
Penyakit Berbasis Lingkungan di Kelurahan Bidara Cina, Jakarta Timur, Jakarta : Universitas Indonesia

Puspita Laksmintari, 2007 Penyakit Kulit dan Kelamin Jakarta : PT Sunda Kelapa Pustaka

Price, S. A. dan Wilson, L. M. 2005. Patofisiologi Konsep Klinis Proses Penyakit. Jakarta: EGC

Ridho Adiputra Tambunan. 2014. Peran Pdam Dalam Pengelolaan Bahan Air Baku Air Minum Sebagai Perlindungan Kualitas Air Minum di Kota Yogyakarta. Yogyakarta : Universitas Atma Jaya Yogyakarta

Soedarto, 2012, Alergi dan Penyakit System Ilmu, Jakarta CV Sagung Seto
Sri Adi Sularsito dan Surja Djuanda, 2010, Ilmu Penyakit Kulit dan Kelamin Penerbit FKUI Jakarta

Tri Cahyono, 2014, Pedoman Penulisan Penelitian dan Karya Tulis Ilmiah / Skripsi (edisi revisi ketiga), Purwokerto : Kementrian Kesehatan RI Politeknik Kesehatan Depkes Semarang Jurusan Kesehatan Banyumas

Umi Chanifah, 2014, Hubungan Sanitasi Asrama dan Personal Hygiene dengan Kejadian Scabies di Pondok Pesantren Tahfidzul Qur'an (PPTQ) Al Asy'ariyyah Wonosobo, Purwokerto : Poltekkes Kementrian Kesehatan Semarang

Undang-undang RI No. 4 Tahun 1992 Tentang Perumahan dan Pemukiman 